\title{
Vegetation patch dynamies and tree diversity in a conifer and oak forest in central Mexico
}

Vicente Díaz-Núñez ${ }^{1}$ Joaquín Sosa-Ramírez ${ }^{2,4}$ and Diego R. Pérez-Salicrup ${ }^{3}$

Botamical Sciences 94 (2): 229-240, 2016

DOI: $10.17129 /$ botsci. 284

\section{Abstract}

Mexican conifer and oak forests are very diverse, and represent the vegetation type with the highest timber production in Mexico. Yet, there is little knowledge about the relationship of forest recovery and tree diversity in this type of vegetation. In this study, we analyzed the dynamics of vegetation patches over three time periods covering five decades, within an area in central Mexico dominated by conifer and oak forest. We identified vegetation patches, and evaluated their number and changes in patch size and vegetation cover. We also evaluated the composition and structure of the plant canopy in vegetation plots representing different canopy cover classes. Over the three periods studied, the number and total area of patches remained relatively constant, but an increase in canopy vegetation cover occurred in most vegetation patches. Patch canopies were dominated by the long-lived pioneer tree species Juniperus deppeana and the shrub Arctostaphylos pungens. We suggest that forest management in our study region should focus on facilitating the dominance of pines and oaks in sites that have recovered their canopy cover, and to identify the factors inhibiting succession in patches with less than $10 \%$ vegetation cover.

Key Words: Aguascalientes, conifer-oak forests, forests management, natural protected areas.

\section{Dinámica de parches de vegetación y diversidad arbórea en un bosque de coníferas y encinos del centro de México \\ Resumen}

Los bosques mexicanos de coníferas y encinos son diversos y constituyen el tipo de vegetación más usada para la producción maderable en México. Sin embargo, se conoce poco acerca de las relaciones entre la recuperación y la diversidad en este tipo de vegetación. En el presente estudio, se analiza la dinámica de los parches de vegetación en tres periodos de tiempo durante cinco décadas, dentro de una zona dominada por bosques de coniferas y encinos, localizada en el centro de México. Se identificaron parches de vegetación y se evaluaron los cambios tanto en número como en el tamaño y cobertura vegetal. También se evaluaron la composición de especies y la estructura del dosel en parcelas representativas de diferentes clases de cobertura. En los tres periodos estudiados, tanto el número como el área total de los parches permaneció relativamente constante, sin embargo en la mayoría de los parches ocurrió un incremento en la cobertura del dosel. El dosel de los parches fue dominado por la especie arbórea pionera Juniperus deppeana y por la especie arbustiva Arctostaphylos pungens. Se sugiere que el manejo forestal en la region de estudio debe orientarse a facilitar la dominancia de pinos y encinos en los sitios que han recuperado la cobertura del dosel y a identificar los factores que inhiben los procesos de sucesión en los parches con cobertura vegetal igual o menor al $10 \%$.

Palabras clave: Aguascalientes, bosques de coníferas y encinos, manejo forestal, área natural protegida.
Gerencia Estatal de la Comisión Nacional Forestal en Aguascalientes. Aguascalientes, Mexico

${ }^{2}$ Centro de Ciencias Agropecuarias. Universidad Autónoma de Aguascalientes. Aguascalientes, Mexico.

${ }^{3}$ Centro de Investigaciones en Ecosistemas. Universidad Nacional Autónoma de México. Morelia, Michoacán, Mexico

${ }^{4}$ Corresponding author jsosar@correo.uaa.mx 
exican conifer and oak forests support high levels of biodiversity (Rzedowski, 1978; Challenger, 1998), concentrate > $95 \%$ of wood production in Mexico (Pérez-Salicrup et al., 2006; Balvanera et al., 2009), and provide important environmental services that benefit human welfare far beyond their geographical limits. There are, however, few studies on the regeneration and patch dynamics of these forests in Mexico, and about the relationships between patch dynamics and tree diversity (Fulé et al., 2000; Gonzalez-Tagle et al., 2008). Conifer and oak forests were largely converted to agriculture since the beginning of Spanish colonization (1521) on the plateaus and montane valleys of central Mexico (Challenger, 2003). Where such forests are still dominant, their structure, composition and area remain affected by natural and human disturbances, particularly cattle grazing, and forest management (Minnich et al., 2000; Mas et al., 2004, Calderon-Aguilera et al., 2012). In this study we analyze patch dynamics in a conifer and oak forest in Aguascalientes State in Central Mexico, and evaluate the implications for these dynamics in terms of tree diversity preservation.

Disturbances in conifer and oak forests in Mexico, and the variable nature of vegetation recovery, have imposed a dynamic mosaic upon the landscape, comprising vegetation patches of different sizes and degrees of vegetation cover (Minnich et al., 2000; Jardel-Peláez et al., 2004). Within the landscape, a patch is defined as a surface that can be differentiated from its surroundings by differences in properties such as plant species composition or percentage of vegetation cover (Pickett and White, 1985; Forman and Godron, 1986). Understanding the transitions, pathways, and dynamics of vegetation cover in these patches is fundamental for the implementation of appropriate management practices in these forests, particularly in areas under conservation.

The Sierra Fria, located in the southern part of the Sierra Madre Occidental in Central Mexico, was declared a Natural Protected Area by the Aguascalientes State Government (Gobierno del Estado de Aguascalientes, 1994). This region apparently was not heavily affected by agricultural conversion or by timber and firewood extraction during the period between the arrival of the Spaniards and the beginning of the $20^{\text {th }}$ century, probably because access from the main population centers of the time was difficult and no major human settlements had been established within these mountains (Minnich et al., 1994). However, this situation changed drastically between 1920 and 1950, when roads were built, connecting these mountains to the city of Aguascalientes, and tree felling in the Sierra Fria forests increased in order to produce posts, charcoal, and timber (Minnich et al., 1994). At least two saw mills were established within the Sierra Fria during that period. Nevertheless, as fossil fuels replaced charcoal for domestic use during the 1950s, and also partly as a consequence of a nation wide ban on timber harvesting in the same decade, timber extraction in the forests of the Sierra Fria was drastically reduced, and the forests began to regenerate. This history of human disturbances, and associated vegetation recovery processes, has produced a heterogeneous mosaic of vegetation patches in the Sierra Fria (Minnich et al., 1994; Chapa-Bezanilla et al., 2008). Today, the vegetation is dominated by white oaks and conifers (see below). Although Sierra Fria is a State protected area, most of the land is still privately owned. Land owners work together with State authorities to plan and implement a management plan.

Several studies have evaluated plant succession in response to changes in land use across different ecosystems. For example, in the temperate forests of the northeastern United States of America (Foster, 1992; Foster et al., 1997) and the tropical forests of Puerto Rico (MarcanoVega et al., 2002; Grau et al., 2003), human migration from rural to urban areas has allowed plant succession to re-establish forest cover. The rate and degree to which these secondary forests acquire a composition and structure similar to that of old growth forests can vary drastically across ecosystems, and as a consequence of the intensity of land use practiced (Martin et al., 2004; Kleijn et al., 2006).

In Mexico, there have been very few studies documenting and characterizing the recovery of vegetation as a consequence of reduction in the pressure on forest resources, or as a consequence of land use change (Turner II et al., 2001; Klooster, 2003; López et al., 2006; Mendoza et al., 2011). Because this lack of knowledge is particularly dramatic in conifer and oak forests, in this study we combine analyses of temporal changes in the size and cover of vegetation patches, with an assessment of the current canopy vegetation of patches of different vegetation 
cover classes, to understand forest patch dynamics and its relation to tree and shrub diversity. This information should provide useful to advice on management objectives for the Study area, and will provide new information of conifer and oak forest patch dynamics.

\section{Material and methods}

Study site. The present study was conducted in dry conifer-oak forest within the Sierra Fria Natural Protected Area (SF-NPA), decreed in 1994, and located in the northwest of the State of Aguascalientes, Central Mexico, at 21 $1^{\circ} 31^{\prime}-23^{\circ} 52^{\prime} \mathrm{N}$ and $102^{\circ} 22^{\prime}-102^{\circ} 50^{\prime} \mathrm{W}$ (Gobierno del Estado de Aguascalientes, 1994). Elevations in the studied region range between 2,200 and 3,050 $\mathrm{m}$, where the geoforms are dominated by volcanic mesas and their associated ravines, covering around 70,000 ha. Mean annual temperature is $17^{\circ} \mathrm{C}$, and the region receives $600 \mathrm{~mm}$ of rain year ${ }^{-1}$, concentrated mostly during June - August. Mature forest vegetation is dominated by Pinus leiophylla Schltdl. \& Cham. and P. teocote Cham. \& Schltdl, Quercus potosina Trel., Q. eduardii Trel., and Q. sideroxyla Bonpl (Siqueiros, 1989). Despite its protected status, low density breeding of domestic cattle, firewood extraction, and hunting are still conducted in the SFPNA. The first two activities are concentrated mostly on sites with slopes $<10 \%$ and close to roads, while the latter is practiced throughout most of the reserve, but with little impact on vegetation, except in a few small $(<0.5 \mathrm{ha})$ scattered oat plantations established to attract wild turkey.

Selection and interpretation of images. We analyzed aerial photographs and a satellite image to evaluate the changes in number, size and cover of canopy vegetation in patches (sensu Kennedy and Spies, 2004, 2005). We used three different series of aerial photograph from different dates. The first series was taken in March 1956 and had a scale of 1:50,000; the second series was from April 1970, with a scale of 1:37,500; and the third series were 1:20,000 scale orthophotos taken in March 1993. For the year 2003, we used a satellite $\operatorname{Spot}^{\circledR}$ image with $10 \mathrm{~m}$ of spatial resolution. The 1956 and 1970 aerial photographs were digitized at $600 \mathrm{dpi}$ and georeferenced by the polynomial adjustment method using control points identified in the 1993 orthophoto mosaic (Lillesand, 1982). The digitalization of photographs gave a resolution of $2 \mathrm{~m}$ for each of the aerial photographs, which could be adjusted to the resolution of the 2003 Spot satellite image. All images were projected to NAD 27. Processing, georeferencing and geographical correction of aerial photographs were conducted in the Laboratory of Analysis of Agroecosystems and Natural Resources of the Center of Agricultural Sciences of the Autonomous University of Aguascalientes during 2007 (see Chapa-Bezanilla et al., 2008). The resulting photographic mosaics for the years 1956, 1970 and 1993, and the 2003 Spot satellite image were overlaid in order to detect and study the area and cover of all vegetation patches. Patches were defined as components in the landscape that differed in vegetation cover relative to their surrounding vegetation. The minimum mapping area was 6.5 ha.

Number, size and class of canopy vegetation cover. Vegetation patches were identified in each year of analysis (Figure 1). Patches in each of the four dates for which it had images were classified into one of four categories according to their canopy vegetation cover: $1<10 \%, 2=$ $11-30 \%, 3=31-50 \%$, and $4>50 \%$. Spatial analysis of images was conducted with the program ArcView ${ }^{\circledR}$ Ver. 3.3 (ESRI, 2009) to identify patches and classify their vegetation cover, and the module ArcEdit to measure their patch area.

To compare changes in patch size in the study region, we counted the number of patches that maintained, reduced or increased their area during each one of the three study periods, i.e.: 1956 $-1970,1970-1993$, and $1993-2003$, and also reported the number of patches that experienced a significant change in an area for each of the three periods. We used the typology of Oliver and Larson (1996) to characterize changes within a patch area, which includes increases or reductions in the size of the patches, or having gaps of a different type of vegetation within its limits. We compared the averages size of the patches using a one-way analysis of variance.

To analyze the changes in the canopy vegetation cover of patches in the mixed forest, the number of patches that remained within the same vegetation cover class, or that changed to a lower or higher vegetation cover class are reported in a compound Matrix format, which allows 
A

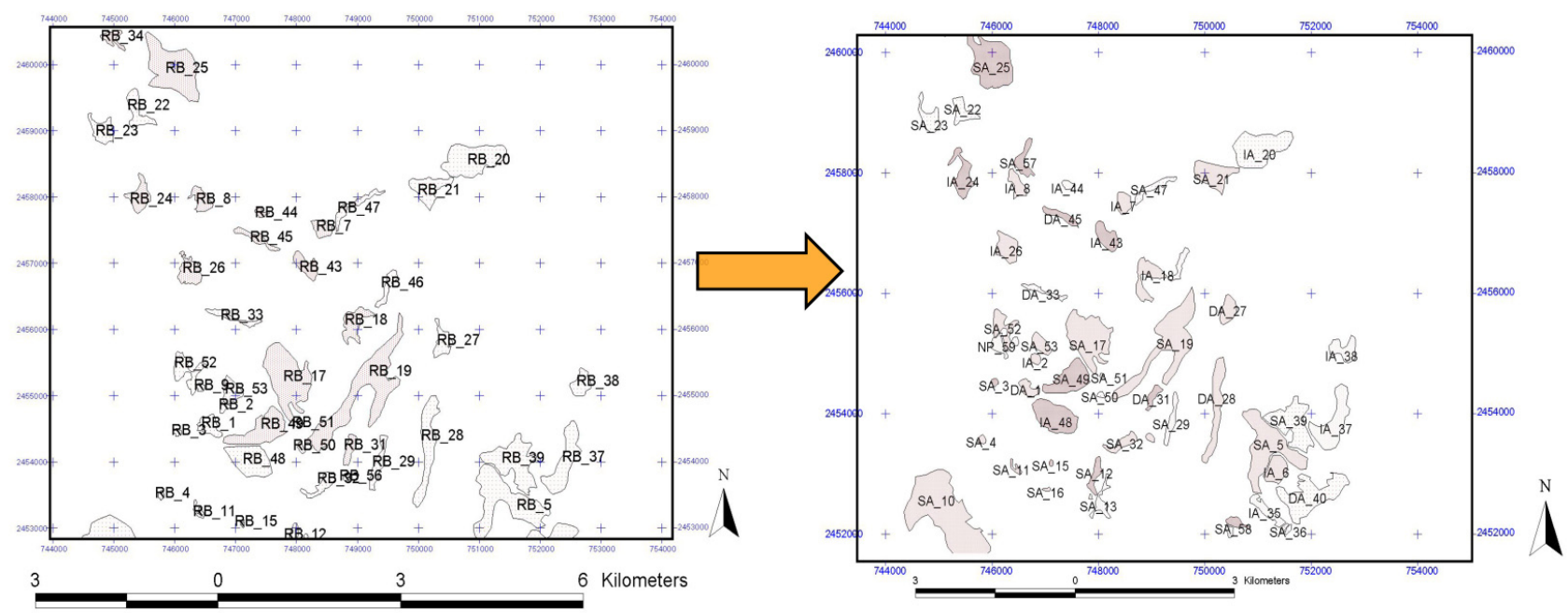

B
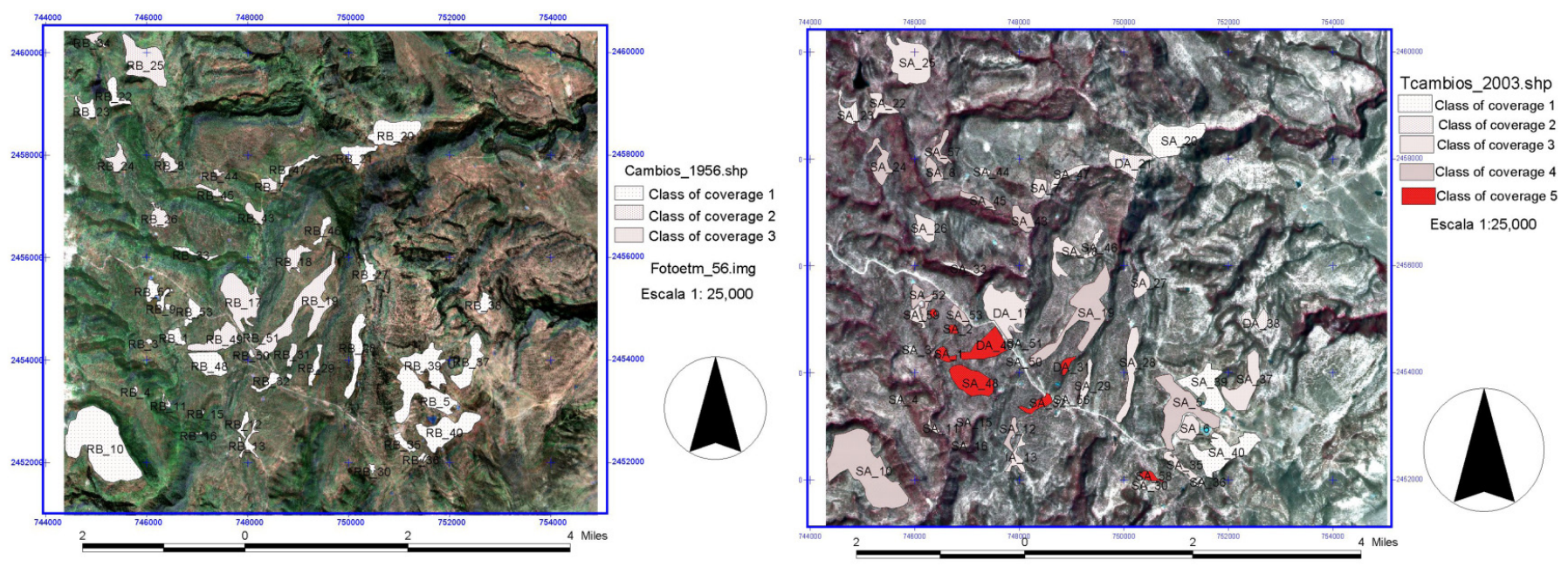

Figure 1. The figure shown the dynamic in the landscape of Sierra Fria Natural Protected Area. A) The figure shown the changes in area of patches in the period 19561993. B) Changes in the coverage in patches of landscape analized the visual inspection of transition changes in each individual time period, and over the whole study period. We evaluated whether the number of patches that changed or remained in the same vegetation cover class was independent of the period of study with a $\chi^{2}$ independence test (Sokal and Rohlf, 1995). We evaluated which of the three periods of analysis was most dynamic in terms of the number of patches that changed in canopy vegetation cover class over the number of years for each particular period.

Description of vegetation of patches with different canopy cover class. We established one vegetation plot in at least five patches for each cover class during the summer of 2008. Plots were squares of $16 \times 16 \mathrm{~m}$, following the recommendations of Daget and Godron (1982), and were established by randomly selecting patches a given vegetation cover class, and then randomly locating each plot within the vegetation patch.

In each plot, we counted, identified and measured the diameter at breast high (DBH; at $1.3 \mathrm{~m})$ of all individual trees $\geq 1.5 \mathrm{~m}$, hereafter considered overstory trees (sensu Fulé and Covington, 1998; Fulé et al., 2000). We also identified and counted trees $0.5-1.5 \mathrm{~m}$ in height, hereafter considered understory trees (sensu Fulé and Covington, 1998; Fulé et al., 2000). In addition, we 
counted, identified and measured the diameter of all shrubs $>0.5 \mathrm{~m}$ in height. We considered shrubs as those individuals with multiple stems at the base of each trunk and lacking a clear single vertical axis (Mabberley, 1997). In shrubs with multiple stems with a DBH of more $\tan 5 \mathrm{~cm}$, we measured the diameter in each stem. With the diameter of trees was estimated the basal area (BA). Species were identified in situ according to the keys proposed by De la Cerda (1989) for oaks, and Siquéiros (1989) for conifers. Identities were corroborated in the herbarium of the Autonomous University of Aguascalientes (HBUAA). We estimated the mean density, basal area, tree diameter, and total species richness, and identified the dominant tree species for overstory trees and shrubs in all vegetation cover classes. For the understory trees, we estimated mean density and species richness. For mean density and basal area of overstory trees, we conducted a simple linear regression, using vegetation cover class as the independent variable, in order to determine whether there was a significant tendency to increase. In addition, we estimated the Shannon-Wiener diversity index as an indicator of alpha tree diversity for overstory trees in all plots, and compared it across classes with a one-way ANOVA. Means and standard errors of the mean are reported throughout this manuscript.

\section{Results}

Number, Size and Canopy Cover of Patches. The overall number of patches remained almost constant throughout the entire period of study $(1956=56,1970=57,1993=58$, and $2003=$ 59). One third of all patches changed their size over the 47 years of analysis. During the first study period (1956-1970), 38 patches maintained their size, two decreased in area, and 15 increased in area; in this period, two new patches appeared different of the first date of analysis (1956), for a total patch area of 12,309.2 ha. During the second period (1970-1993), the number of patches that maintained their size was similar to the first period $(n=36)$, however, although more patches $(n=8)$ decreased in size and less patches increased in size $(n=14)$ compared to the previous period, the total area covered by patches increased by only 321.3 ha. Finally, during the last period (1993-2003) most patches maintained their area $(n=52)$, only three decreased in area, and five increased. In this final period the total area covered by vegetation patches changed less than the minimum mapping area, so we can consider that no change occurred.

Table 1. Matrices representing transitions of patches to different vegetation cover class through three different periods of analysis in the Sierra Fria Protected Natural Area, Mexico. Shaded cells in the diagonal represent number of patches that did not change in vegetation cover through the period. In horizontal comparison of matrices (i.e.: 1970 vs. 1993 and 2003) cells above the diagonal represent the number of patches that moved to a higher class of vegetation cover, while cells below the diagonal represent the number of patches that moved to a lower vegetation cover class. In vertical comparison (i.e.: 1956 vs. 1970, 1993 and 2003) cells above the diagonal represent the number of patches that moved to a lower vegetation cover class, and cells below the diagonal represent the number of patches that moved to a higher vegetation cover class.

\begin{tabular}{|c|c|c|c|c|c|c|c|c|c|c|c|c|c|}
\hline \multirow{2}{*}{$\begin{array}{l}\text { Years of } \\
\text { analysis }\end{array}$} & \multirow{2}{*}{$\begin{array}{l}\text { Vegetation } \\
\text { cover class }\end{array}$} & \multicolumn{4}{|c|}{1956} & \multicolumn{4}{|c|}{1993} & \multicolumn{4}{|c|}{2003} \\
\hline & & 1 & 2 & 3 & 4 & 1 & 2 & 3 & 4 & 1 & 2 & 3 & 4 \\
\hline \multirow[t]{4}{*}{1970} & 1 & 25 & & & & 13 & 9 & 2 & & 11 & 5 & 7 & 4 \\
\hline & 2 & 5 & 10 & & & 1 & 1 & 12 & & & 2 & 4 & 8 \\
\hline & 3 & 3 & 5 & 4 & & 1 & 1 & 6 & & 2 & & 6 & 5 \\
\hline & 4 & 1 & 1 & 3 & & & 1 & 1 & 1 & & 1 & 2 & 2 \\
\hline \multirow[t]{4}{*}{1993} & 1 & 14 & 1 & & & & & & & & & & \\
\hline & 2 & 8 & 1 & 2 & & & & & & & & & \\
\hline & 3 & 10 & 8 & 3 & & & & & & & & & \\
\hline & 4 & 4 & 4 & 3 & & & & & & & & & \\
\hline \multirow[t]{4}{*}{2003} & 1 & 12 & & & & 8 & & 2 & 2 & & & & \\
\hline & 2 & 5 & 2 & 2 & & 4 & 4 & 2 & & & & & \\
\hline & 3 & 8 & 6 & 3 & & 2 & 6 & 10 & 2 & & & & \\
\hline & 4 & 8 & 6 & 5 & & 1 & 3 & 5 & 8 & & & & \\
\hline
\end{tabular}


Table 2. Overstory tree (trees $\geq 1.5 \mathrm{~m}$ in height) community characteristics in plots representing vegetation patches of different canopy cover class in the Sierra Fria Protected Natural Area, Mexico. Numbers in parenthesis represent 1 standard error of the mean.

\begin{tabular}{|c|c|c|c|c|c|c|}
\hline $\begin{array}{l}\text { Vegetation } \\
\text { Cover Class }\end{array}$ & $\begin{array}{l}\text { Number } \\
\text { of plots }\end{array}$ & $\begin{array}{l}\text { Density } \\
\text { Inds/ha }\end{array}$ & $\begin{array}{l}\text { Basal Area } \\
\mathbf{m}^{2} / \mathrm{ha}\end{array}$ & $\begin{array}{l}\text { Shannon } \\
\text { Diversity Index }\end{array}$ & $\begin{array}{l}\text { Dominant } \\
\text { species }\end{array}$ & $\begin{array}{l}\text { Present species } \\
\text { on cover class }\end{array}$ \\
\hline 1 & 5 & 0 & 0 & 0 & ------------ & ----------- \\
\hline 2 & 5 & $712(280.62)$ & $16.1(4.20)$ & $0.9307(0.403)$ & J. deppeana & $\begin{array}{l}\text { J. deppeana, Q. potosina, A. pungens, } \\
\text { Q. potosina, P. cembroides, P. leiophylla, } \\
\text { Q. grisea, A. Xalapensis, Q. eduardii }\end{array}$ \\
\hline 4 & 5 & $1515(251.00)$ & 30.5 (1.96) & $0.8186(0.343)$ & J. deppeana & $\begin{array}{c}\text { J. deppeana, A. pungens, Q. potosina, } \\
\text { Q. grisea, A. xalapensis }\end{array}$ \\
\hline
\end{tabular}

During the period 1956-1970, 1.21 patches changed in area per year, while 0.96 and 0.80 patches per year changed in area during $1970-1993$ and $1993-2003$, respectively. The types of changes observed in patch size were either reductions or increases in patch area (sensu Kennedy and Spies, 2004; Hummel and Cunningham, 2006). We did not observe changes in patch area associated with the development of a different patch within a patch, nor patches that increased in size and then decreased, or vice versa. Mean patch size over the four dates of observation was not significantly different, $1956=201.8$ (Standard error of the mean, $\mathrm{SE}=7.88 \mathrm{ha}$ ), $1970=$ $212.7(\mathrm{SE}=7.68 \mathrm{ha}), 1993=220.3(\mathrm{SE}=7.48 \mathrm{ha})$, and $2003=217.3(\mathrm{SE}=7.48 \mathrm{ha})$.

Similar to patch size, vegetation cover class was also very dynamic over the four different years of observation. From the 59 patches present in the final period of analysis, only 17 $(28.8 \%)$ remained unchanged from the first year of observation (Table 1). Twelve of these unchanged patches remained within the lowest vegetation cover category. The number of patches that changed in the canopy vegetation cover category was not independent of the period of study analyzed $\left(\chi^{2}=14.1\right.$, d.f. $\left.=2, P=0.001\right)$. Over the first period, 1956-1970, 39 patches remained in the same canopy vegetation cover class, 18 advanced to a higher cover class, while none regressed to a lower class category. During 1970 - 1993, 22 patches remained in the same canopy vegetation cover class, 31 advanced to a higher class, and 5 regressed to a lower class. During the final period, 1993 -2003, 21 patches remained in the same canopy vegetation cover class, 33 advanced and 5 regressed in class, respectively (Table 1). The number of patches that changed in vegetation cover per year increased from 1.3 in $1956-1970$, to 1.6 in $1970-1993$, and to 1.8 from $1993-2003$. The number of patches that advanced to a higher vegetation cover class per year remained almost equal at 1.3 patches per year during the first two studied periods, but increased to 3.3 during 1993- 2003.

Table 3. Understory tree (trees $0.5-1.5 \mathrm{~m}$ in height) community characteristics in plots representing vegetation patches of different canopy cover class in the Sierra Fria Protected Natural Area, Mexico. Numbers in parenthesis represent 1 standard error of the mean.

\begin{tabular}{ccccc}
$\begin{array}{c}\text { Vegetation } \\
\text { Cover Class }\end{array}$ & $\begin{array}{c}\text { Number } \\
\text { of plots }\end{array}$ & $\begin{array}{c}\text { Density } \\
\text { Inds/ha }\end{array}$ & $\begin{array}{c}\text { Dominant } \\
\text { species }\end{array}$ & $\begin{array}{c}\text { Present species } \\
\text { on cover class }\end{array}$ \\
\hline 1 & 5 & $234(128.3)$ & J. deppeana & J. deppeana \\
2 & 5 & $752(258.3)$ & J. deppeana & $\begin{array}{c}\text { J. deppeana, A. pungens, } \\
\text { Q. potosina }\end{array}$ \\
3 & 15 & $953(154.8)$ & J. deppeana & $\begin{array}{c}\text { J. deppeana, A. pungens, } \\
\text { Q. potosina, Q. grisea, Q. rugosa } \\
4\end{array}$ \\
5 & $1367(377.1)$ & J. deppeana & J. deppeana, A. pungens \\
\hline
\end{tabular}


Table 4. Shrub community characteristics in plots representing vegetation patches of different canopy cover class in the Sierra Fria Protected Natural Area, Mexico. Numbers in parenthesis represent 1 standard error of the mean

\begin{tabular}{|c|c|c|c|c|c|}
\hline $\begin{array}{l}\text { Vegetation } \\
\text { Cover Class }\end{array}$ & $\begin{array}{l}\text { Number } \\
\text { of plots }\end{array}$ & $\begin{array}{l}\text { Density } \\
\text { Inds/ha }\end{array}$ & $\begin{array}{c}\text { Basal Area } \\
\mathbf{m}^{2} / \mathrm{ha}\end{array}$ & $\begin{array}{l}\text { Dominant } \\
\text { tree species }\end{array}$ & $\begin{array}{l}\text { Present species } \\
\text { on cover class }\end{array}$ \\
\hline 1 & 0 & ----------- & 0 & ---------- & \\
\hline 2 & 3 & $404(318.1)$ & $1.3(1.16)$ & A. pungens & A. pungens, J. deppeana, Q. grisea, P. Leophylla \\
\hline 3 & 4 & $801(709.6)$ & $5.5(5.10)$ & A. pungens & A. pungens, J. deppeana, Q. microphylla \\
\hline
\end{tabular}

Vegetation in Patches with Different Cover Class. We did not find any overstory trees in vegetation patches of canopy cover class 1 (Table 2). For the other three canopy cover categories, we found a significant increase in tree density $\left(r^{2}=0.16, \mathrm{~F}=4.15, P<0.05\right)$, and basal area $\left(r^{2}=\right.$ $0.27, \mathrm{~F}=8.12, P<0.01)$ as canopy vegetation cover class increased. Species richness and diversity, however, did not differ between the three vegetation cover classes where trees were found (Table 2). In all of these, the dominant species was Juniperus deppeana Steud. The density of understory trees increased significantly in vegetation patches with higher categories of canopy vegetation cover $\left(r^{2}=0.27, F=9.88, P=0.04\right)$, but the number of species did not differ (Table $3)$. Interestingly, J. deppeana was the dominant tree species for both over- and understory trees across all canopy vegetation cover classes where trees were found. We did not find any shrubs in canopy cover classes 1 and 4 (Table 4). In the intermediate canopy cover classes (categories 2 and 3), shrub density, basal area, and number of species did not differ. The dominant shrub species was Arctostaphylos pungens Kunth. (Table 4).

Overall, in all plots we recorded two juniper species (Juniperus deppeana Steud, and $J$. flaccida Schltdl.), five species of oaks (Quercus rugosa Née, Q. potosina, Q. grisea Liemb., Q. chihuahuensis Trel., and Q. eduardii Trel), and three species of pines (Pinus leiophylla, $P$. chihuahuana Engelm, and P. cembroides Zucc.). Shrubs were represented by Arbutus xalapensis Kunth, Arctostaphylos pungens, Prunus serotina Ehrh., and Pithecellobium leptophyllum (DC.) Daveau.

\section{Discussion}

During the 47 years period analyzed in this study, we observed a relatively constant number of vegetation patches in the SFNPA which had a general tendency to increase in vegetation cover. This general trend is consistent with the decreased intensity of human activity in the region and the subsequent recovery of natural vegetation, particularly after the 1950's when large scale timber extraction was reduced significantly (Minnich et al., 1994).

Human activity and catastrophic natural disturbances can increase the number and extension of patches within a matrix of mature vegetation during discrete events and over relatively short time periods (Foster, 1988; Kennedy and Spies, 2004, 2005). In this study, both the number of patches and the area covered by patches remained practically unchanged during the whole period of analysis, reflecting the fact that most human activities conducted after 1956 did not involve the removal of large expanses of natural vegetation, and that no large scale catastrophic natural disturbances affected this region during any of the three periods of study.

Although the surface covered by patches and the mean patch area were practically constant, almost one third of all analyzed patches changed their size beyond the minimum mapping area. Both the number of patches changing in area per year, and the proportion of patches that enlarged their area decreased in the three consecutive study periods. This trend suggests that, although large scale timber harvesting was reduced significantly just before the first study period, edge effect related disturbances in some patches (see Laurance et al., 2007) or selective low scale timber extraction might have caused some patches to increase in area, but these processes became less common as time advanced from 1956. Because the average patch area of patches 
did not change over the three study periods, the effects of patch size increases did not affect the landscape to any considerable degree.

Vegetation recovery is evident from the general trend towards increases in patch canopy cover categories. However, the rate of change was not constant over the three periods of study, since more patches changed vegetation cover classes per year during $1993-2003$ than in the previous two periods. Minnich et al. (1994) suggested that human pressure exerted on Sierra Fria ceased towards the 1950's, and that the landscape would be expected to be undergoing a clear recovery by 1970 . Our results suggest that recovery, as expressed in terms of canopy cover increase in patches, was detectable even from the first period of study (1956 - 1970), but this process occurred at higher rates with each consecutive period.

The governmental decree established the Sierra Fria as a protected area was made in 1994, shortly after the beginning of the last period of analysis evaluated in this study (1993 - 2003), and hence coinciding with the period when more patches per year increased in canopy vegetation cover. However, it is difficult to evaluate whether the increased rate of transition of patches to higher vegetation cover classes in this final period is related directly to the decree, or if it reflects a continuing trend of increasing canopy density as time and succession progressed in vegetation patches following the cessation of timber extraction. It has been observed that in only $17 \%$ of the 93 natural protected areas analyzed in different parts of the world there has been a clear detectable process of vegetation recovery (Nagendra, 2008). It appears that in SFNPA, as in other parts of Mexico, the establishment of protected areas in sites where there had been a previous change in land use is an effective strategy towards reducing deforestation, and increasing vegetation recovery (Bray et al., 2008).

While there was a general trend of vegetation recovery in the Sierra Fria, especially in the coniferous and oak vegetation, a number of patches presented reductions in vegetation cover. From our visits to some of these vegetation patches, and from previous work in the region, we observed that patches that changed to a category with less vegetation cover were those affected by incidences of insects (Díaz-Núñez et al., 2006) and wood diseases (Oliver and Larson, 1996), and had undergone the associated extraction of infected individuals as a management practice. We saw no evidence that these patches were affected by cattle or other direct human activity.

Natural recovery of canopy vegetation through secondary succession is a process that still needs to be fully described and understood in Mexican conifer and oak forests growing in sites where timber harvesting was practiced (Park, 2001; Jardel-Peláez et al., 2004; González-Tagle et al., 2008). Secondary succession involves the sequential turnover of species and the establishment of a plant canopy following disturbance (Chazdon et al., 2008), and it proceeds at different rates in different ecosystems. Because Mexican conifer and oak forests grow in a wide diversity of conditions (Rzedowski, 2006; Sánchez-Velásquez et al., 2009), it is likely that the process of succession will have important variations associated with local site effects. In our study, we assumed that a description of vegetation in patches of the four analyzed canopy cover classes would resemble different phases of canopy recovery through succession.

As would be expected, density and basal area of overstory trees, as well as density of understory trees, increased substantially with increasing canopy cover class. However, the number of species and diversity (this last parameter only recorded for overstory trees) did not present such an increase. In all vegetation patches where trees were present, Juniperus deppeana was the dominant species, both for overstory and understory trees. In the study zone, this species is clearly a pioneer tree which can establish in open, disturbed sites, but apparently it remains a dominant component of the canopy for as long as 50 years. In contrast, in other pine forests in Mexico, where succession has been evaluated, pine species become the dominant species after 18 years, and then oak trees eventually gain dominance (Quintana-Ascencio et al., 1992; Jardel-Pelaez et al., 2004; González-Tagle et al., 2008). In certain sites, some of which are affected by fires, pine trees remain dominant (Fulé and Covington, 1998; Fulé et al., 2000; Park, 2001).

One probable explanation for the permanence of Juniperus deppeana as the dominant tree species in patches with different canopy cover at our site is the presence of cattle, that inhibit the establishment of oak and oak-pine seedlings in the Sierra Fria. In Mexico, there are not many 
studies about the ecological conditions of J. deppeana; nevertheless, Rzedowsky (1978) and Vázquez-Yanes et al. (2002) suggest that the dominance of the species is consequence of the overgrazing and wild fires. It has been reported that several pine and oak species are very sensitive to cattle grazing and, in the case of the latter, to direct solar radiation (Quintana-Ascencio et al., 1992; Gribko et al., 2002; Foster and Tilman, 2003). Therefore, the removal of livestock from the forest region, and the establishment of a J. deppeana canopy could result in the eventual establishment of pine and oak species in these regenerating vegetation patches (Van Lear, 2004; Borman, 2005). By the other hand, is probable that the dominance of Arctostaphylos pungens in some ecological sites, is due to wild fires occurrence in the SFNPA, similar that appear in the Michilia, Durango State (Márquez-Linares et al., 2005).

We expected that shrubs would be more abundant in patches in the more open canopy cover categories ( 1 and 2 ), and that their abundance would then decrease as overstory tree density increased in canopy vegetation classes 3 and 4 . However, we only found shrubs in vegetation patches with a canopy cover of $11-50 \%$. This suggests that the shrub species encountered in our site may require a minimum quantity of trees to become established, but they disappear as the canopy closes and trees become dominant.

Although we found four species of shrubs, Arctostaphylos pungens was clearly the most dominant species. It is important to note that in our study site Arbutus xalapensis and Prunus serotina grew as shrubs, but these species can grow as trees in more mesic sites outside of our study region.

Of the 25 patches of vegetation with $<10 \%$ canopy cover in 1956, 12 had not increased their canopy cover by 2003. Because we did not conduct a land use assessment of all patches, we cannot determine whether these patches remained with such low canopy cover values as a consequence of repeated human related disturbances, or as a consequence of an impediment with secondary succession. Differentiating between these two possible causes would be necessary in order to identify the appropriate actions towards ensuring that these patches recover their tree cover over time, but it is apparent that active restoration might be required in these sites (Hobbs and Norton, 1996; Chazdon, 2008).

Although most of the patches have experienced a recovery in vegetation cover class in the study region, the displacement of those believed to be originally oak (Quercus spp.) and pine (Pine spp.) groves, and the colonization of these sites by Juniperus deppeana and Arctostaphylos pungens communities might reduce habitat and food availability for fauna that depend on conifers and oaks, such as the dotted owl (Strix occidentalis lucida; Márquez-Olivas et al., 2002), wild turkey (Meleagris gallopavo), and the white tail deer (Odoicoleus virginianus) (Gribko et al., 2002).

From this study, we can conclude that management and future research on vegetation patches in SFNPA should concentrate on two important restoration objectives: first, for those sites where canopy cover has apparently increased in the past five decades, it is important to understand why pines and oaks have not regained dominance. In this sense, it would be appropriate to evaluate whether the dominance of Juniperus deppeana and Arctostaphylos pungens inhibits the establishment and survival of pine and oak seedlings. Similarly, it is important to evaluate qualitatively the impact of cattle on the establishment of seedlings of these two genera in this site. Second, it is important to identify the barriers that have impeded the regeneration of a tree and shrub canopy in some patches for almost 50 years.

\section{Acknowledgements}

The authors would like to tank Daniel Chapa-Bezanilla for facilitating the aerial photographs for the first two periods of analyses, Nahum Hernández-Quiroz for field work support, and Carlos Zermeño-Benítez, who helped with photographic analyses. Our Thanks also to the Consejo Nacional de Ciencia y Tecnología (CONACYT) of México for funding this study, and to Manuel Mendoza Cantú, Ernesto Alvarado and Carlos Urban Haubi for useful comments on previous versions of this manuscript. We acknowledge too for the suggestions and commentaries of two anonymous reviewers. 


\section{Literature cited}

Balvanera P., Cotler H., Aburto-Oropeza O., Aguilar-ContrerasA., Aguilera-Peña M., Aluja M., AndradeCetto A., Arroyo-Quiroz I., Ashworth L., Astier M., Avila P., Bitrán-Bitrán D., Camargo T., Campo J., Cárdenas-González B., Casas A., Díaz-Fleischer F., Etchevers J.D., Ghillardi A., González-Padilla E., Guevara A., Lazos E., López-Sagástegui C., López-Sagástegui R., Martínez J., Masera O., Mazari M., Nadal A., Pérez-Salicrup D., Pérez-Gil R., Quesada M., Ramos-Elorduy J., Robles-González A., Rodríguez H., Rull J., Suzán G.H., Vergara C.H., Xolalpa-Molina S., Zambrano L. and Zarco A. 2009. Estado y tendencias de los servicios ecosistémicos. En: Dirzo R., González R. y March I. Eds. Capital natural de México Volumen II: Estado de Conservación y Tendencias de Cambio. Comisión Nacional para el Conocimiento y Uso de la Biodiversidad, México D.F.

Borman M.M. 2005. Forest stand dynamics and livestock grazing in historical context. Conservation Biology 19:1658-1662.

Bray D.B., Duran E., Ramos V.H., Mas J.F., Velázquez A., McNab R.B., Barry D. and Radachovsky J. 2008. Tropical deforestation, community forest and protected areas in the Maya forest. Ecology and Society 13:56.

Calderon-Aguilera L.E., Rivera-Monroy V.H., Porter-Bolland L., Martínez-Yrízar A., Ladah L.B., Martínez-Ramos M., Alcocer J., Santiago-Pérez A.L., Hernández-Arana H.A., Reyes-Gómez V.M., PérezSalicrup D.R., Díaz-Nuñez V., Sosa-Ramírez J., Herrera-Silveira J. and Búrquez A. 2012. An assessment of natural and human disturbance effects on Mexican ecosystems: current trends and research gaps. Biodiversity and Conservation 21:589-617.

Challenger A. 1998. Utilización y Conservación de los Ecosistemas Terrestres de México: Pasado, Presente y Futuro. Comisión Nacional para el Conocimiento y Uso de la Biodiversidad/Universidad Nacional Autónoma de México México D.F.

Challenger, A. 2003. Conceptos generales acerca de los ecosistemas templados de montaña de México y su estado de conservación. En: Sánchez, O., E. Vega, E. Peters y O. Monroy-Vilchis (Eds). Conservación de ecosistemas templados de montaña en México. INE-SEMARNAT. ISBN: 968-817-610-9. Pp. 17-44.

Chapa-Bezanilla D., Sosa-Ramírez J. y de Alba-Ávila A. 2008. Estudio multitemporal de fragmentación de los bosques en la Sierra Fría, Aguascalientes, México. Madera y Bosques 14:37-51.

Chazdon R. L. 2008. Beyond deforestation: restoring forest and ecosystem services on degraded lands. Science 320:1458-1460.

Daget Ph. and Godron M. 1982. Analyse de l'Ecologie des Espèces dans les Communautés. Masson, Paris.

Díaz-Núñez V., Sánchez-Martínez G. y Gillette N.E. 2006. Response of Dendroctonus mexicanus (Hopkins) to two optical isomers of vervenone. Agrociencia 40:349-354.

De la Cerda Lemus M.E. 1989. Encinos de Aguascalientes. Universidad Autónoma de Aguascalientes, Aguascalientes.

ESRI [Environmental Systems Research Institute]. 2009.. ArcView version 3.3.Redlands, California. Available in: http://www.esri.com/software/arcgis/arcgisonline

Forman R.T.T. and Godron M. 1986. Landscape Ecology. John Wiley \& Sons, New York.

Foster D.R. 1988. Disturbance history community organization and vegetation dynamics of the old-grow Pisgah forest south-western New Hampshire, USA. Journal of Ecology 76:105-134.

Foster D.R. 1992. Land-use history (1730-1990) and vegetation dynamics in central New England, USA. Journal of Ecology 80:753-772.

Foster D.R., Aber J.D., Melillo J.M., Bowden R.D. and Bazzaz F.A. 1997. Forest response to disturbance and anthropogenic stress. BioScience 47:437-445.

Foster B.L. and Tilman D. 2003. Seed limitation and the regulation of community structure in oak savanna grassland. Journal of Ecology 91:999-1007.

Fulé P.Z. and Covington W.W. 1998. Spatial patterns of Mexican pine-oak forests under different recent fire regimes. Plant Ecology 134:197-209.

Fulé P.Z., García-Arévalo A. and Covington W.W. 2000. Effects of an intensive wildfire in a Mexican oakpine forest. Forest Science 46:52-61.

Gobierno del Estado de Aguascalientes. 1994. Declaratoria del Área Natural protegida Sierra Fría, Aguascalientes, Diario Oficial Ags. Tomo LVII, No. 5. Órgano del Gobierno Constitucional del Estado, Aguascalientes.

González-Tagle M.A., Schwendenmann L., Jiménez-Pérez J. and Schulz R. 2008. Forest structure and woody plant species composition along a fire chronosequence in mixed pine-oak forest in the Sierra Madre Oriental, Northeast Mexico. Forest Ecology and Management 256:161-167.

Grau H.R., Aide T.M., Zimmerman J.K., Thomlinson J.R., Elmer E. and Zou X. 2003. The ecological consequences of socioeconomic and land-use changes in postagriculture Puerto Rico. BioScience 56:1159-1168. 
Gribko L.S., Schuler T.M. and Ford W.M. 2002. Biotic and abiotic mechanisms in the establishment of northern red oak seedlings: a review. General Technical Report NE-295. USDA Forest Service, Newtown Square

Hobbs R.J. and Norton D.A. 1996. Towards a conceptual framework for restoration ecology. Restoration Ecology 4:93-110.

Hummel S. and Cunningham P. 2006. Estimating variation in a landscape simulation of forest structure. Forest Ecology and Management 228:135-144.

Jardel-Peláez E.J., Santiago-Pérez A.L., Cortez-Montaño C. and Castillo-Navarro F. 2004. Sucesión y dinámica de rodales, pp. 179-203. En: Cuevas-Guzmán R. and Jardel-Peláez E.J. Eds. Flora y Vegetación de la Estación Científica Las Joyas. Universidad de Guadalajara, Guadalajara.

Kennedy R.S.H. and Spies T.S. 2004. Forest cover changes in the Oregon Coast Range from 1939 to 1993. Forest Ecology and Management 200:129-147.

Kennedy R.S.H. and Spies T.S. 2005. Dynamics of hardwood patches in a conifer matrix: 54 years of change in a forested landscape in Coastal Oregon, USA. Biological Conservation 122:363-374.

Klooster D. 2003. Forest transitions in Mexico: institutions and forests in a globalized countryside. The Professional Geographer 55:227-237.

Kleijn D., Baquero R.A. Clough Y., Díaz M., De Esteban J., Fernández F., Gabriel D., Herzog F., Holzschuh A., Jöhl R., Knop E., Kruess A., Marshall E.J., Stefan-Dewenter I., Tscharntke T., Verhulst J., West TM. and Yela J.L. 2006. Mixed biodiversity benefits of agri-environment schemes in five European countries. Ecological letters 9:243-254.

Laurance W.F., Nascimento H.E.M., Laurance S.G., Andrade A., Ewers R.M., Harms K.E., Luizão R.C.C. and Ribeiro J.E. 2007. Habitat fragmentation, variable edge effects, and the landscape-divergence hypothesis. PLOS ONE 2:e1017.

Lillesand T.M. and Kieffer R.W. 1982. Remote Sensing and Image Interpretation. John Wiley \& Sons, New York.

López E., Bocco G., Mendoza M., Velásquez A. and Aguirre-Rivera J.R. 2006. Peasant emigration and land-use change at the watershed level: a GIS-based approach in central Mexico. Agricultural Systems 90:62-78.

Mabberley D.J. 1997. The Plant Book: A Portable Dictionary of the Vascular Plants. Cambridge University Press, Cambridge.

Marcano-Vega H., Aide M.T. and Báez B. 2002. Forest regeneration in abandoned coffee plantations and pastures in the cordillera central of Puerto Rico. Plant Ecology 161:75-87.

Márquez-Olivas M., Tarango-Arámbula L.A. and Mendoza-Martínez G.D. 2002. Caracterización del hábitat del tecolote moteado mexicano. Agrociencia 36:541-546.

Márquez-Linares M.A., Jurado E. and López-González C. 2005. Efecto del fuego en el establecimiento de Arctostaphylos pungens Hbk., en ecosistemas templados semihúmedos, de Durango, México. Madera y Bosques 11:35-48.

Martin P.H., Sherman R.E. and Fahey T.J. 2004. Forty years of tropical forest recovery from agriculture: Structure and floristics of secondary and old-growth riparian forests in the Dominican Republic. Biotropica 36:297-317.

Mas J.-F., Velázquez A., Reyes-Díaz-Gallegos J., Mayorga-Saucedo R., Alcántara C., Bocco G., Castro R., Fernández T. and Pérez-Vega A. 2004. Assesing land use, cover changes: a nationwide multidate spatial database for Mexico. International Journal of Applied Earth Observation and Geoinformation 5:249-261.

Mendoza M.E., López-Granados E., Geneletti D., Pérez-Salicrup D.R. and Salinas V. 2011. Analysing land cover and land use change processes at watershed level: A multitemporal study in the Lake Cuitzeo Watershed, Mexico (1975-2003). Applied Geography 31:237-250.

Minnich R.A., Sosa-Ramírez J., Franco V.E., Barry W.J. and Siquéiros M.E. 1994. Reconocimiento preliminar de la vegetación y de los impactos de las actividades humanas en la Sierra Fría, Aguascalientes, México. Investigación y Ciencia 12:23-29.

Minnich R.A., Barbour M.G., Burk J.H. and Sosa-Ramírez J. 2000. Californian mixed-conifer forests under unmanaged fire regimes in the Sierra San Pedro Mártir, Baja California, Mexico. Journal of Biogeography 27:105-129.

Nagendra H. 2008. Do parks work? Impact of protected areas on land cover clearing. Ambio 37:330-337.

Oliver C.D. and Larson B.C. 1996. Forest Stand Dynamics (Update edition). John Wiley \& Sons, New York.

Park A.D. 2001. Environmental influences on post-harvest natural regeneration in Mexican pine-oak forests. Forest Ecology and Management 144:213-228.

Pickett S.T.A. and White P.S. 1985. The Ecology of Natural Disturbance and Patch Dynamics. Academic Press, Inc., Orlando.

Pérez-Salicrup D.R., Peñaloza-Guerrero C. and Aguiar-Eleutério A.A. 2006. Regeneration of Styrax ar- 
Received:

October 20th, 2014

Accepted:

February 12th, 2015 genteus in natural forest and in plantations of Cupressus lindleyi in Michoacan, Mexico. New Forests 32:231-241.

Quintana-Ascencio P.F., González-Espinosa M. and Ramirez-Marcial N. 1992. Acorn Removal, Seedling Survivorship, and Seedlings Growth of Quercus crispipilis in Successional Forests of the Highlands of Chiapas, Mexico. Bulletin of the Torrey Botanical Club 119:6 -18.

Rzedowski J. 1978. Vegetación de México. Limusa, México D.F.

Rzedowsky J. 2006. Vegetación de México. $1^{\text {a }}$ Edición digital, Comisión Nacional para el Conocimiento y Uso de la Biodiversidad. México. 504 p.

Sánchez-Velásquez L.R., Pineda-López M.R., Galindo-González J., Díaz-Fleischer F. and ZúñigaGonzález J.L. 2009. Opportunity for the study of critical successional processes for the restoration and conservation of mountain forest: the case of Mexican Pine plantations. Interciencia 34:518-522.

Siqueiros D.M.E. 1989. Coníferas de Aguascalientes. Universidad Autónoma de Aguascalientes, Aguascalientes.

Sokal R.R. and Rohlf F.J. 1995. Biometry: The Principles and Practice of Statistics in Biological Research. W.H. Freeman and Co., New York.

Turner II B.L., Cortina-Villar S., Foster D., Geoghegan J., Keys E., Klepeis P., Lawrence D., MacarioMendoza P., Manson S., Ogneva-Himmelberger Y., Plotkin A.B., Pérez-Salicrup D., Chowdhury R.R., Savitsky B., Schneider L., Schmook B. and Vance C. 2001. Deforestation in the Southern Yucatán Peninsular Region: an integrative approach. Forest Ecology and Managent 154:353-370.

Vázquez-Yanez C., Batis-Muñoz A.I., Alcocer-Silva M.I., Gual-Díaz M. and Sánchez-Dirzo C. 2002. Árboles y arbustos nativos potencialmente valiosos para la restauración ecológica y la reforestación. Proyecto J-084 Instituto de Ecología, Universidad Nacional Autónoma de México y Comisión Nacional para el Uso y Conservación de la Biodiversidad, México D.F.

Van Lear D.H. 2004. Upland Oak Ecology and Management. In Spetich M.A Ed. Upland oak ecology symposium: history, current conditions, and sustainability. Geneneral Technical Repport SRS-73. USDA Forest Service, Asheville 